\title{
MELIOLACEAE OF KERALA, INDIA-XX THREE NEW SPECIES AND ONE NEW VARIETY OF GENUS MELIOLA
}

\author{
V.B. Hosagoudar
}

Microbiology Division, Tropical Botanic Garden and Research Institute, Palode, Thiruvananthapuram, Kerala 695562, India Email: hosagoudar@hotmail.com

\begin{abstract}
This paper gives an account of five Meliola species. Of these, Meliola cassiae-fistulae, M. desmodii - triangularis and M. triquetri are the new species and $\mathrm{M}$. capensis var. dimocarpi is the new variety. Meliola memecyli var. microspora forms the new record to India. All these species are described and illustrated in detail.
\end{abstract}

KEY WORDS

India, Kerala, Meliola, new species, new variety

ABBREVIATIONS
HCIO - Herbarium Cryptogamae Indiae Orientalis, New Delhi; TBGT - Tropical Botanic Garden, Thiruvananthapuram

Meliola capensis var. dimocarpi V. B. Hosagoudar et A. Manojkumar, var. nov. (Fig. 1)

\begin{abstract}
Material examined
Type: 14.x.2002, Deer Rehabilitation Centre, Thenmala, Kollam, Kerala, coll. A. Manojkumar, on leaves of Dimocarpus longan Lour. (Sapindaceae), HCIO 44690.

Isotype: 14.x.2002, Deer Rehabilitation Centre, Thenmala, Kollam, Kerala, coll. A. Manojkumar, on leaves of Dimocarpus longan Lour. (Sapindaceae), TBGT 971.
\end{abstract}

\section{Diagnostic features}

Similis Meliola capensis (Kalch. \& Cooke) Theiss. var. baileyana Hansf. differt a appressoriis et ascosporis brevioribus.

Colonies epiphyllous, dense, crustose to velvety, up to $2 \mathrm{~mm}$ in diameter, confluent. Hyphae straight, branching alternate at acute to wide angles, loosely to closely reticulate, cells $17-21 \mathrm{x}$ $5-7 \mu \mathrm{m}$. Appressoria opposite, about 1\% solitary, antrorse, 14$16 \mu \mathrm{m}$ long; stalk cells cylindrical to cuneate, $3-5 \mu \mathrm{m}$ long; head cells ovate, conoid, entire, attenuated and broadly rounded at the apex, 10-12 x 7-9 $\mu \mathrm{m}$. Phialides mixed with appressoria, alternate to opposite, ampulliform, 18-23 x 5-7 $\mu \mathrm{m}$. Mycelial setae numerous, simple, straight, very few flexuous, curved to uncinate, acute, obtuse, acute to 2-4 times dentate at the tip, up to $400 \mu \mathrm{m}$ long. Perithecia scattered, globose, up to $125 \mu \mathrm{m}$ in diameter; ascospores oblong, 4-septate, constricted at the septa, 32-34 x 12-15 $\mu \mathrm{m}$.

\section{Remarks}

Opposite appressoria with conoid head cells and simple to denate mycelial setae brings the present collection to Meliola capensis (Kalch. \& Cooke) Theiss. group (Hansford, 1961). The Beeli Formula $31^{1 / 3} 2.3222$ brings it closer to M. capensis (Kalch. \& Cooke) Theiss. var. baileyana Hansf. However, the new variety differs from it in having shorter appressoria and smaller ascospores.

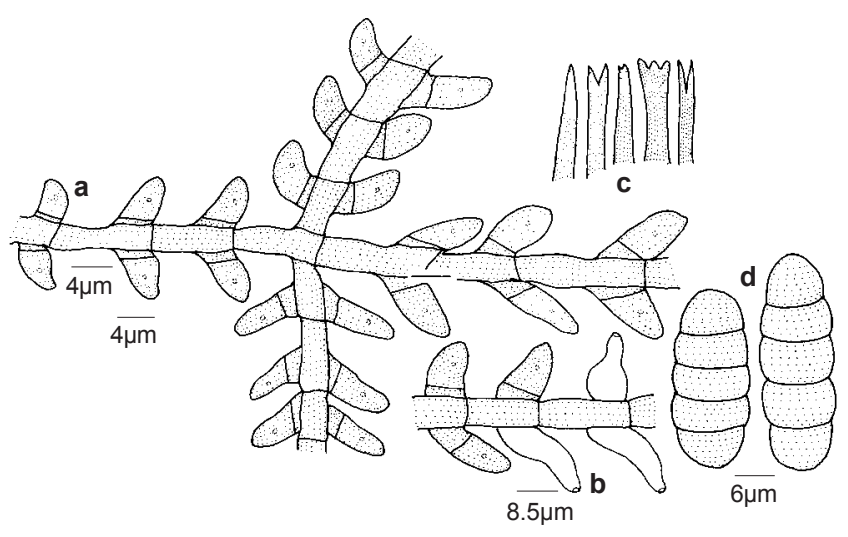

Figure 1. Meliola capensis var. dimocarpi, var. nov. a - Appressorium; b - Phialide; c - Mycelial setae; d - Ascospores

\section{Meliola cassiae-fistulae \\ V. B. Hosagoudar et A. Manojkumar, sp. nov.} (Fig. 2)

\section{Material examined}

Type: 4.x.2002, Parakuzhy forest, Karikulam, Ranni, Pathanamthitta, Kerala, India, coll. A. Manojkumar, on leaves of Cassia fistula L. (Caesalpiniaceae), HCIO 44707.

Isotype: 4.x.2002, Parakuzhy forest, Karikulam, Ranni, Pathanamthitta, Kerala, India, coll. A. Manojkumar, on leaves of Cassia fistula L. (Caesalpiniaceae), TBGT 988.

\section{Diagnostic features}

Coloniae epiphyllae, subdensae, ad $3 \mathrm{~mm}$ diam. Hyphae subrectae vel flexuosae, alternate, opposite vel irregulariter acuteque vel laxe romosae, laxe reticulatae, cellulae 19-23x 4-6 $4 \mathrm{~m}$. Appressoria alternata, ad 1\% opposita, antrorsa vel subantrorsa, 12-16 $\mathrm{m}$ longa; cellulae basilares cylindraceae vel cuneatae, 3-4 $\mathrm{m}$ longae; cellulae apicales ovatae, globosae, integrae, curvulae, 9-13 x 9-10 $\mu$ m. Phialides mixtus appressoriis, alternate vel opposite, ampulliformes, 14-16x 


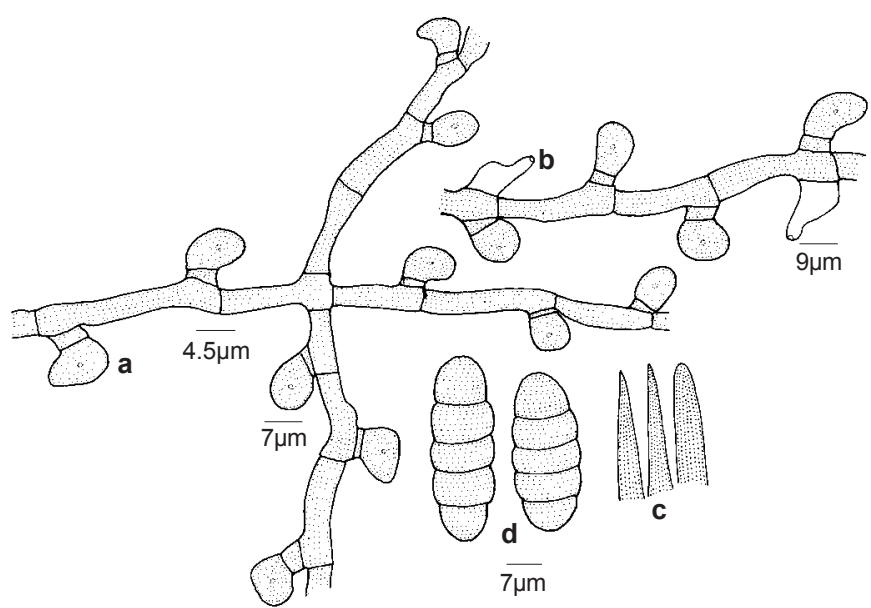

Figure 2. Meliola cassiae-fistulae sp. nov. a - Appressorium; b - Phialide; c - Mycelial setae; d - Ascospores

8-10 $4 \mathrm{~m}$. Setae myceliales paucae, simplices, rectae, acutae vel obtusae ad apicem, ad 300 $\mu$ m longae. Perithecia dispersa,

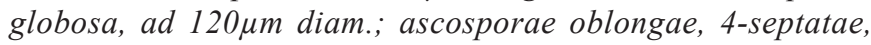

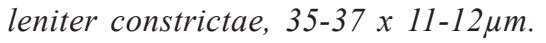

Colonies epiphyllous, subdense, up to $3 \mathrm{~mm}$ in diameter. Hyphae substraight to flexuous, alternate, opposite to irregular at acute to wide angles, loosely reticulate, cells 19-23 x 4-6 $\mu \mathrm{m}$. Appressoria alternate, about $1 \%$ opposite, antrorse to subantrorse, 12-16 $\mu \mathrm{m}$ long; stalk cells cylindrical to cuneate, 3$4 \mu \mathrm{m}$ long; head cells ovate, globose, entire, curved, 9-13 x 9$10 \mu \mathrm{m}$. Phialides many, mixed with appressoria, alternate to opposite, ampulliform, 14-16 x 8-10 $\mu$ m. Mycelial setae very few, simple, straight, acute to obtuse at the tip, up to $300 \mu \mathrm{m}$ long. Perithecia scattered, globose, up to $120 \mu \mathrm{m}$ in diameter; ascospores oblong, 4-septate, slightly constricted, 35-37 x 11$12 \mu \mathrm{m}$.

\section{Remarks}

Meliola aethiops Sacc. is known on this host genus but the new species differs from it in having alternate appressoria, few mycelial setae and smaller ascospores (Hansford, 1961). It also differs from M. aethiops Sacc. var. cassiae Rao in having straight setae in contrast to torulose and having smaller ascospores (Hosagoudar et al., 1997).

\section{Meliola desmodii-triangularis V.B. Hosagoudar et A. Manojkumar, sp. nov.} (Fig. 3)

\section{Material examined}

Type: 4.x.2002, Placherry forest, Ranni, Pathanamthitta, Kerala, coll. A. Manojkumar, on leaves of Desmodium triangulare (Retz.) Merr. (Fabaceae), HCIO 44695.

Isotype: 4.x.2002, Placherry forest, Ranni, Pathanamthitta, Kerala, coll. A. Manojkumar, on leaves of Desmodium triangulare (Retz.) Merr. (Fabaceae), TBGT 976.

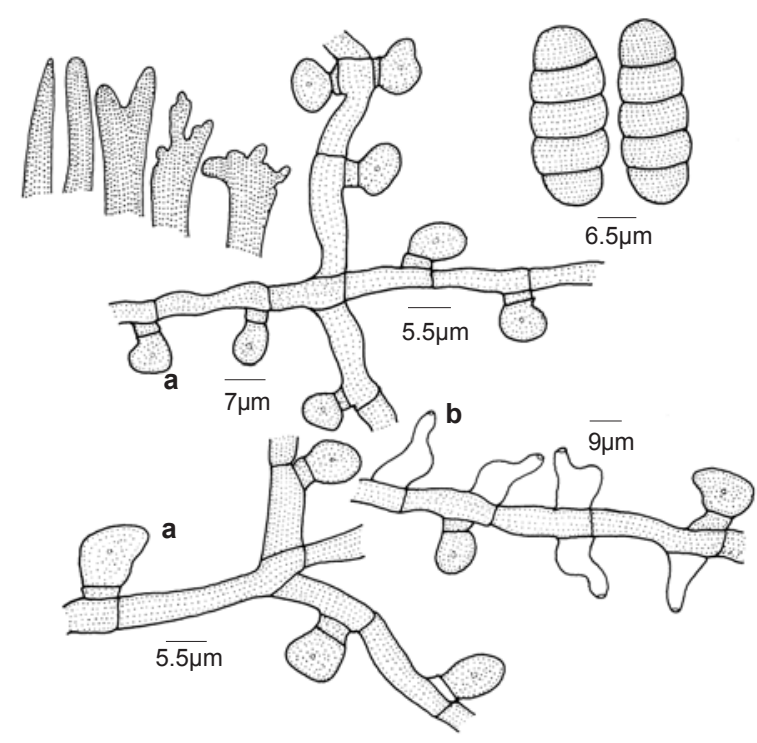

Figure 3. Meliola desmodii-triangularis sp. nov. a - Appressorium; b - Phialide; c - Mycelial setae; d - Ascospores

\section{Diagnostic features}

Coloniae epiphyllae, valde tenuis, ad $2 \mathrm{~mm}$ diam., raro confluentes. Hyphae subrectae, flexuosae vel raro anfractuae, alternate vel irregulariter acuteque vel laxe ramosae, laxe vel dense reticulatae, cellulae 22-28 x 4-5 $\mu \mathrm{m}$. Appressoria alternata, unilateralia, ad 8\% opposita, antrorsa, subantrorsa vel recurvata, recta vel curvula, 11-16 1 m longa; cellulae basilares cylindraceae vel cuneatae, 2-5 apicales plerumque globosae, raro ovatae, integrae, saepe variae curvulae, 8-12x8-11 $\mu$ m. Phialides numerosae, mixtus appressoriis, alternate vel opposite, ampullaceae, 12-21x6$8 \mu \mathrm{m}$. Setae myceliales juxta perithecia aggregatae, simplices, rectae vel leniter curvulae, acutae, obtusae vel 2-4 ter dentatae vel cristatae ad apicem, ad $300 \mu \mathrm{m}$ longae. Perithecia dispersa, globosa, ad $130 \mu \mathrm{m}$ diam.; ascosporae oblongae, 4septatae, constrictae, $28-32 \times 9-12 \mu \mathrm{m}$.

Colonies epiphyllous, very thin, up to $2 \mathrm{~mm}$ in diameter, rarely confluent. Hyphae substraight, flexuous to rarely crooked, branching alternate to irregular at acute to wide angles, loosely to closely reticulate, cells $22-28 \times 4-5 \mu \mathrm{m}$. Appressoria alternate, unilateral, up to $8 \%$ opposite, antrorse, subantrorse to recurved, $11-16 \mu \mathrm{m}$ long; stalk cells cylindrical to cuneate, $2-5 \mu \mathrm{m}$ long; head cells mostly globose, rarely ovate, entire, often variously curved, $8-12 \times 8-11 \mu \mathrm{m}$. Phialides many, mixed with appressoria, alternate to opposite, ampulliform, 12-21 x 6-8 $\mu \mathrm{m}$. Mycelial setae scattered to grouped around perithecia, simple, straight to slightly curved, acute, obtuse to 2-4 times dentate to cristate at the tip, up to $300 \mu \mathrm{m}$ long. Perithecia scattered, globose, up to $130 \mu \mathrm{m}$ in diameter; ascospores oblong, 4-septate, constricted at the septa, $28-32 \times 9-12 \mu \mathrm{m}$.

\section{Remarks}

Of the known nine species of the genus Meliola on the host genus Desmodium, the present species can be compared with 


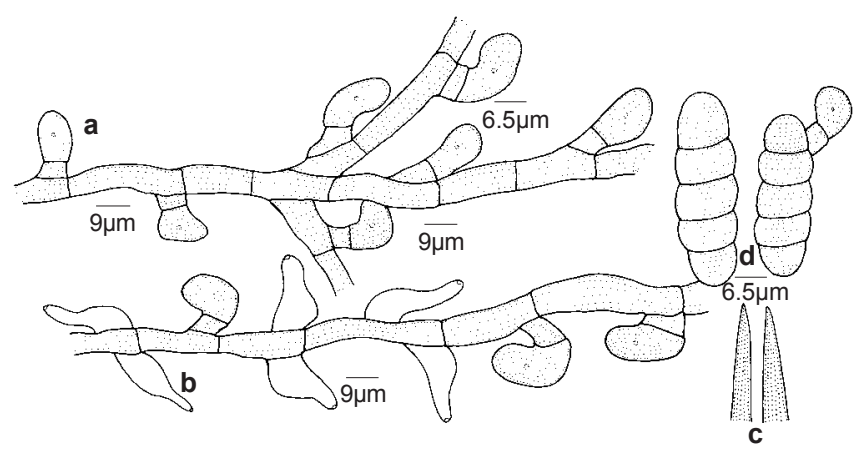

Figure 4. Meliola desmodii-triquetri sp. nov. a - Appressorium; b - Phialide; c - Mycelial setae; d - Ascospores

M. constipata Speg. having simple and dentate mycelial setae (Hansford, 1961). However, differs from it in having acute, obtuse, 2-4 dentate to cristate mycelial setae and having distinctly smaller ascospores.

\section{Meliola desmodii-triquetri} V.B. Hosagoudar et A. Manojkumar, sp. nov. (Fig. 4)

\section{Material examined}

Type: 4.x.2002, Parakuzhy, Karikulam, Ranni forest, Pathanamthitta, Kerala, coll. A. Manojkumar, on leaves of Desmodium triquetrum (L.) DC. (Fabaceae), HCIO 44694.

Isotype: 4.x.2002, Parakuzhy, Karikulam, Ranni forest, Pathanamthitta, Kerala, India, coll. A. Manojkumar, on leaves of Desmodium triquetrum (L.) DC. (Fabaceae), TBGT 975.

\section{Diagnostic features}

Coloniae hypophyllae, tenues, patentiae, ad $5 \mathrm{~mm}$ diameter, confluentes. Hyphae subrectae vel flexuosae, alternate, opposite vel irregulariter acuteque vel laxe ramosae, laxe vel dense reticulatae, cellulae 25-35 x 4-5 $\mu \mathrm{m}$. Appressoria alternata, ad 5\% opposita, antrorsa vel retrorsa, recta vel

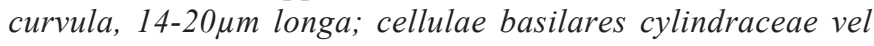
cuneatae, 4-8 4 m longae; cellulae apicales ovatae, globosae, integrae, rectae vel variae curvulae, 9-12 $\times$ 9-11 $\mu \mathrm{m}$. Setae myceliales dispersae, simplices, rectae, acutae ad apicem, ad $300 \mu \mathrm{m}$ longae. Perithecia dispersa, globosa, ad $144 \mu \mathrm{m}$ diam.; ascosporae oblongae, 4-septatae, leniter constrictae, 32-40 $x$ 11-14 $\mu \mathrm{m}$.

Colonies hypophyllous, thin, spreading, up to $5 \mathrm{~mm}$ in diameter, confluent. Hyphae substraight to flexuous, branching alternate, opposite to irregular at acute to wide angles, loosely to closely reticulate, cells 25-35 x 4-5 $\mu \mathrm{m}$. Appressoria alternate, about 5\% opposite, antrorse to retrorse, straight to curved, $14-20 \mu \mathrm{m}$ long; stalk cells cylindrical to cuneate, $4-8 \mu \mathrm{m}$ long; head cells ovate, globose, entire, straight to variously curved, 9-12 x 9-11 $\mu \mathrm{m}$. Phialides many, mixed with appressoria, alternate to opposite, ampulliform, 16-24 x 6-8 $\mu \mathrm{m}$. Mycelial setae scattered, simple, straight, acute at the tip, up to $300 \mu \mathrm{m}$ long. Perithecia scattered, globose, up to $144 \mu \mathrm{m}$ in diameter; ascospores oblong, 4-septate,

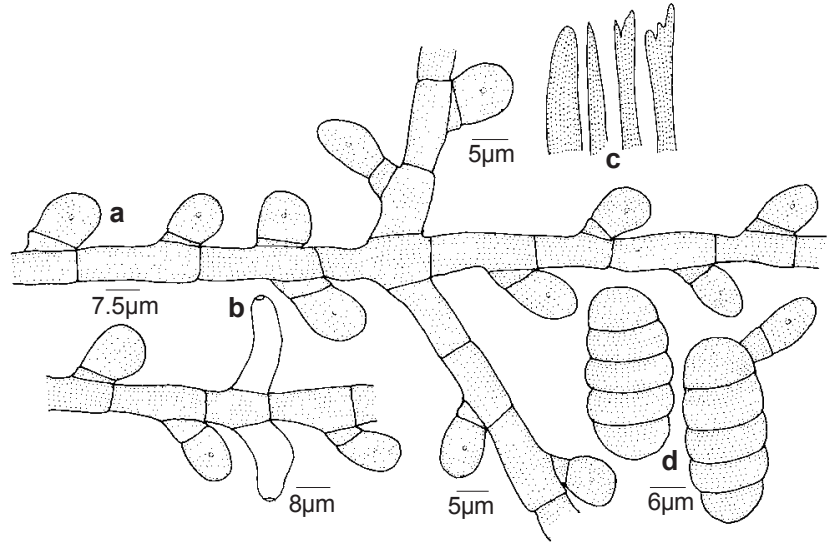

Figure 5. Meliola memecyli Sydow var. microspora Hansf. a - Appressorium; b - Phialide; c - Mycelial setae; d - Ascospores

slightly constricted at the septa, $32-40 \times 10-14 \mu \mathrm{m}$.

\section{Remarks}

Based on the Beeli formula 3113.3221, the present collection can be compared with Meliola desmodii Karst \& Roum. var. heterochaeta Cif. known on Desmodium supinum from San Domingo (Hansford, 1961). However, Hansford (1961) stated that it is incompletely studied material. In such case, the present species stands distinct and hence, it has been placed under a new species.

\section{Meliola memecyli Sydow var. microspora Hansf. (Fig. 5)}

Sydowia 10:68, 1957; Hansf., Sydowia Beih. 2: 156, 1961.

\section{Material examined}

3.x.2002, Vandanam Sacred grove, Alapuzha, Kerala, coll. A. Manojkumar, on leaves of Memecylon edule Roxb. (Melastomataceae), HCIO 44701, TBGT 982.

\section{Diagnostic features}

Colonies epiphyllous, dense, crustose, up to $2 \mathrm{~mm}$ in diam., confluent. Hyphae straight, branching opposite at wide angles, loosely to closely reticulate, cells $22-24$ x 6-7 $\mu \mathrm{m}$. Appressoria alternate, about $2 \%$ opposite, antrorse to subantrorse, $16-18 \mu \mathrm{m}$ long; stalk cells cylindrical to cuneate, 3-4 $\mu \mathrm{m}$ long; head cells ovate, entire, $12-14$ × 9-11 $\mu \mathrm{m}$ in diameter. Phialides mixed with appressoria, alternate to opposite, ampulliform, 20-24 x 8-10 $\mu \mathrm{m}$. Mycelial setae mostly grouped around perithecia, simple, straight, acute, obtuse to dentate at the tip, up to $800 \mu \mathrm{m}$ long. Perithecia scattered, globose, up to $190 \mu \mathrm{m}$ in diameter; ascospores oblong, 4-septate, strongly constricted at the septa, $36-40 \times 16-18 \mu \mathrm{m}$.

\section{Remarks}

In the present collection, very few appressoria are opposite. Otherwise, the present collection perfectly matches with the species assigned. This species was reported from Philippines and was known only from a type collection and is known here 
Table 1. A comparative account of Meliola species on the genus Desmodium

\begin{tabular}{|c|c|c|}
\hline Beeli formula & Other characters of the species & Name of the species \\
\hline 3111.3223 & Colonies thin, hyphae crooked; head cells ovate, bent and angulose-lobate; mycelial setae acute & bantamensis \\
\hline 3111.4222 & Colonies epiphyllous; mycelial setae all dentate at the tip; ascospores $33-43.5 \mu \mathrm{m}$ long & desmodii-laxiflori var. dentatae \\
\hline 3111.4232 & Colonies dense, velvety; head cells globose to ovate; often bent; mycelial setae acute; spores narrow & desmodi-laxiflori \\
\hline 3113.3221 & Mycelial setae mostly simple and obtuse & desmodi var. heterochaeta \\
\hline 3113.3221 & $\begin{array}{l}\text { Colonies hypophyllous, thin; hyphae substraight; appressoria straight to curved, head cells entire; } \\
\text { ascospores } 32-38 \times 11-30 \mu \mathrm{m}\end{array}$ & desmodii-triquetri \\
\hline 3113.3222 & $\begin{array}{l}\text { Colonies epiphyllous; hyphae substraight; appressoria rarely opposite, head cells entire; } \\
\text { ascospores } 32-38 \times 11-30 \mu \mathrm{m}\end{array}$ & desmodi pulchelli \\
\hline 3113.3222 & Colonies thin; hyphae tortuous; head cells ovate, globose, mycelial setae obtuse to acute & meibomiae \\
\hline 3113.4220 & Appressoria spreading to antrorse; phialides mixed with appressoria, ascospores $35-40 \mu \mathrm{m}$ long & bantamensis var. keralensis \\
\hline 3113.4221 & $\begin{array}{l}\text { Colonies dense, crustose, caulicolous; hyphae substraight; appressoria crowded, head cells globose; } \\
\text { mycelial setae numerous, acute. }\end{array}$ & kawandensis \\
\hline 3113.4223 & $\begin{array}{l}\text { Colonies thin to dense, sometimes velvety; hyphae straight to crooked; head cells globose, } \\
\text { usually small; mycelial setae acute or } 2-4 \text { dentate. Phialides frequently crowded }\end{array}$ & bicornis \\
\hline $31 \frac{1}{3} 3.3231$ & $\begin{array}{l}\text { Colonies epiphyllous, very thin; hyphae substraight to crooked; head cells of appressoria globose, entire, } \\
\text { variously curved }\end{array}$ & desmodii - triangularis \\
\hline $31 \frac{1}{3} 3.4221$ & Colonies dense, velvety; hyphae substraight; head cells ovate, pyriform; mycelial setae bi- dentate & constipata \\
\hline
\end{tabular}

for the first time from India (Bilgrami et al., 1991).

\section{REFERENCES}

Bilgrami, K.S., S. Jamaluddin and M.A. Rizwi (1991). Fungi of India. List and References. Today and Tomorrow's Printers \& Publishers, New Delhi, 798pp.

Hansford, C.G. (1961). The Meliolinceae. A Monograph. Sydowia. Beih 2:1-806.

Hosagoudar, V.B. (1996). Meliolales of India. Botanical Survey of India, Calcutta, 363pp.

Hosagoudar, V.B., T.K. Abraham and P. Pushpangadan (1997). The Meliolineae - A Supplement. Tropical Botanic Garden and Research Institute, Palode, Thiruvananthapuram, Kerala, India, 201pp.

\section{ACKnowledgements}

Thanks are due to Dr. G.M. Nair, Director and Dr. T.K. Abraham, Deputy Director, TBGRI, Palode for the facilities. 